\title{
CAMPO DE CONCENTRAÇÃO: EXPERIÊNCIA LIMITE
}

\author{
Marion Brepohl de Magalhães*
}

\begin{abstract}
É um homem quem mata, é um homem quem comete ou suporta injustiças; não é um homem que, perdida já toda a reserva, compartilha a cama com um cadáver. Quem esperou que seu vizinho acabasse de morrer para tirar-lhe um pedaço de pão, está mais longe (embora sem culpa) do modelo do homem pensante do que o pigmeu mais primitivo ou do sádico mais atroz. Uma parte de nossa existência está nas almas de quem se aproxima de nós; por isso, não é humana a experiência de quem viveu dias nos quais o homem foi apenas uma coisa ante os olhos de outro homem.
\end{abstract}

Primo Levi

\begin{abstract}
RESUMO
O objetivo deste artigo é o estudo de alguns aspectos da violência exercida nos campos de concentração da Alemanha nazista, considerando os elementos de cristalização que predispuseram os indivíduos a praticarem ou tolerarem o ato extremista. Analiso também, no tocante à violência contra o pensamento, as relações entre memória e História, valendo-me do testemunho de um sobrevivente que fez de toda a sua atividade intelectual um esforço para compreender o significado daquilo que tornou possível e memorável Auschwitz.
\end{abstract}

Palavras-chave: campos de concentração, violência, memória.

* Professora Adjunta da Universidade Federal do Paraná. Bolsista do CNPq. 


\begin{abstract}
The aim of this article is the study of some aspects of the violence excercised in Nazi Germany's concentration camps, taking into account the facts that led people to participate in extremely violent actions or to tolerate them. It also analyses, in terms of violence against thought, the relationship between memory and History, founded on the testimony of one of the survivors who directed all his intellectual activities to the effort of understanding the significance of all that made Auschwitz possible and unforgettable.
\end{abstract}

Key-words: concentration camps, violence, memory.

O tema proposto - a violência nos campos de concentração da Alemanha nacional-socialista - é, possivelmente, menos inintelígível no campo da Literatura do que no campo da História. Além de ser a linguagem estética mais identificada com metáforas e de sua aproximação à consciência trágica - de quem é tributária -, ela permite aproximar o leitor da experiência do narrado. Quanto a nós, os historiadores e demais cientistas sociais, encontramos enormes dificuldades em nomear o acontecimento. Dificuldade que decorre de nossa incapacidade de atribuir-lhe significado. Isto porque estamos conscientes de que a "história constitui-se na diferença entre intenção e resultado das ações" humanas (RÜSEN, 1997, p. 127). Ora, no que se refere às intenções, a historiografia aponta para algumas respostas: confirmar a não humanidade daqueles prisioneiros, treinar pessoas para serem capazes de exercer qualquer sorte de brutalidade, a ideologia da limpeza étnica; ...mas, quanto aos resultados, esta é uma questão ainda em aberto: muitos sobreviventes estão por testemunhar, reclamam-se políticas que reparem aqueles crimes, há processos não concluídos, há inclusive o revisionismo, ${ }^{1}$ uma estupidez que pretende provar que o que aconteceu não aconteceu, mas que é, não obstante a isto, um dos resultados daqueles acontecimentos.

Ademais, a História, cuja tarefa é a de racionalizar o passado, defronta-se, com relação a esse tema, com a memória, que insiste em mantê-lo

1 Refiro-me aqui ao revisionismo histórico, corrente política que nega ou minimiza a experiência do holocausto. A este respeito, ver: FELDMANN, S. 1945: hora zero de um novo tempo. Cinquentenário da Segunda Guerra Mundial. Curitiba: Instituto Goethe / Programa de Pós-graduação em História da Universidade Federal do Paraná, 1995. p. 24-31. 
vivo, continuamente presentificado, principalmente no seio da comunidade judaica. Insistência que assume, conforme Seixas, "uma dimensão ética e política, pois este passado deve nos deixar alerta sobre sistemas novos, e no entanto, análogos" (2000, p. 77).

Para iniciar nossa tarefa, cito alguns termos utilizados para nomear o que foi feito nos campos de concentração, os quais evidenciam a dificuldade que mencionei.

Holocausto: como tal acontecimento foi inicialmente denominado e como ficou mais amplamente conhecido, é um termo impreciso, quase um eufemismo; deriva da palavra sacrifício - no sentido literal, significa "totalmente queimado", dizendo respeito aos sacrifícios de animais que se faziam aos deuses, logo, um ato voluntário dedicado ao Sagrado. Ora, nem o elemento religioso nem qualquer hipótese de livre opção estiveram presentes, fossem da parte das vítimas, fossem dos perpetradores.

Shoah: também de origem bíblica, significa extermínio, catástrofe, devastação, ${ }^{2}$ pressupondo um castigo. Novamente, o termo não se aplica, porquanto as vítimas não foram presas por algum erro ou crime e, mesmo que o tivessem sido, a pena não era executada em nome de um mandato divino. Como afirma Primo Levi, sobre seu povo: “...Nós , afinal de contas, provamos também uma certa co-responsabilidade humana, pois Auschwitz era uma obra de homens, e nós somos homens..." (1998, p. 216)

Mesmo se nos dispusermos a nos colocar no lugar dos perpetradores - tarefa que se impõe ao historiador, como nos ensinou Lucien Febvre - e conseguirmos compreender que, para os nazistas, os judeus representavam um mal à raça ariana, por que maltratar os moribundos, os agonizantes? ${ }^{3}$ Ainda, com relação aos que não eram inimigos da raça, como os comunistas, os clérigos e os Testemunhas de Jeová, por que não lhes conceder a chance do arrependimento? ${ }^{4}$

2 Como esclarece Giorgio AGAMBEM (1999, p. 37), o termo foi inspirado no Livro de Isaías 10:3, a propósito da ira divina contra o povo de Israel: "Que fareis vós no dia do castigo, quando de longe virá o shoah?"

3 Sobre o tratamento aos doentes, ver: LEVI, P. Conversations et entretiens. Paris: R. Laffont, 1998. p. 211 et seq.

4 Desses grupos, apenas aos Testemunhas de Jeová se lhes concedia a oportunidade de livramento, sob a condição de renunciarem à sua fé. A este respeito, ver: Os Testemunhas de Jeová resistem ao ataque nazista. Sociedade de Vigia de Bíblias e Tratados: Associação Cultural Boas Novas Eternas, 1997. (Vídeo). 
Poderíamos entender o holocausto ou o shoah como uma provação? Um sofrimento de difícil resistência para provar a fé? Certamente houve muitos que mantiveram a sua fé e isso inclusive lhes conferiu força para sobreviverem, mas, do ponto de vista religioso, não foram os que melhor se comportaram que sobreviveram. Ademais, nem mesmo os nazistas podiam acreditar que aquele sofrimento provinha de Deus.

Era o inferno então? Recordo-me de Hannah Arendt ter empregado, certa vez, o termo inferno terreno para a tortura que se impunha aos prisioneiros nos campos de concentração (1993, p. 70). O inferno, como foi concebido pela cosmovisão judaico-cristã à época medieval, não era o lugar da morte, mas do sofrimento eterno, de um sofrimento tão grande, que as pessoas preferiam morrer a ter de suportá-lo. É bem verdade que semelhante sensação devem ter tido aqueles prisioneiros, mas lembremonos de que, tanto nos textos religiosos como na cultura popular, o inferno é a habitação do Diabo e o Diabo não é de natureza humana. Em Auschwitz, não foi alguém com poderes sobrenaturais ou alguém estranho à espécie quem ordenou que se infligisse sofrimento aos prisioneiros. Foram homens comuns, que procediam inclusive do mesmo meio social de muitas de suas vítimas.

Afora isso, destaco que não foram alguns, mas milhões; destaco ainda a ausência de simetria entre crime e punição; destaco o sofrimento inútil; destaco que eram cidadãos comuns transformados em assassinos.

Faço este breve percurso sobre alguns termos e noções derivadas do universo religioso porque foram estes os primeiros termos empregados pela comunidade judaica, esta com mais difíceis razões para nomear o ocorrido, e também por entender que do Sagrado provêm muitas palavras que povoam o imaginário social - sejamos crentes ou não.

Apliquemo-nos agora aos termos adotados no meio secular.

No campo da Psicologia, afirma-se terem sido os nazistas submetidos à pressão psicológica, o que os teria levado à uma obediência cega às autoridades (MILGRAM, 1969) ou que, nos campos de concentração, teria ocorrido uma regressão filogenética, retornando os homens a um comportamento semelhante ao de seus anscestrais da horda primitiva (BETTELHEIM, 1969). Esta situação justifica muitos dos atos, mas não é causa suficiente, cabal. Pois mesmo na horda, conforme os antropólogos, os homens se organizam para sobreviver, e não matam senão em defesa própria. E quanto ao autoritarismo, muitas vezes ele provoca mais a rebeldia do que 
a submissão. De resto, seria possível a concentração numérica de tantas perversões em um único universo ao mesmo tempo?

Crime: por certo é o termo mais apropriado se levarmos em conta a responsabilidade que todo o cidadão tem de responder pelo que faz perante a lei; mas poderíamos entender como crime os atos praticados pelos próprios judeus ou ciganos, quando organizavam as filas de indivíduos que deveriam entrar nas câmaras de gás? Chamaríamos de crime quem roubou um sapato no inverno ou delatou o outro por ter roubado pão?

Tortura: historicamente, a tortura foi um método legal ou estatal para forçar uma pessoa a falar a verdade, constituindo um método de repressão de tendência secular (PETERS, 1985). A tortura explica uma grande parte dos fatos, se por tortura entendermos que esta

\begin{abstract}
...busca, à custa do sofrimento corporal insuportável, introduzir uma cunha que leve à cisão entre o corpo e a mente. E mais do que isto: ela procura, a todo o tempo, semear a discórdia e a guerra entre o corpo e a mente. Através da tortura, o corpo torna-se nosso inimigo e nos persegue (...) da mais íntima espessura da própria carne, se levanta uma voz que nos nega, na medida em que pretende arrancar de nós um discurso do qual temos horror, já que é a negação de nossa liberdade (PELLEGRINO, apud BRASIL NUNCA MAIS, 1985, p. 281282).
\end{abstract}

Isso também ocorreu. Muitos tiveram, como afirma Levi, suas almas e suas vontades massacradas. Mas, nos campos de concentração, ninguém exigia que os prisioneiros falassem, confessassem alguma verdade. Pelo contrário, a ordem era para que sofressem em silêncio.

Michel Foucault, em um de seus últimos escritos, mencionou que se tratava de uma guerra de raças, produto da centralização da ideologia racista nas mãos do estado (1999). Mas qual guerra levaria a que os combatentes procurassem apagar os vestígios de sua vitória?

Genocídio: sim, este é um nome bem próximo das intenções da elite nazista, que o designou como a Endlösung, mas os assassinatos não se limitaram a um só povo ou a uma única cultura - foram presos testemunhas de Jeová, ciganos, homossexuais, doentes físicos e mentais, membros de partidos de esquerda. 
O trabalho escravo foi empregado, mas, de novo, insisto na tese da assimetria: ali, o trabalho era desprovido de qualquer valor utilitário e boa parcela da mão-de-obra era eliminada antes mesmo de tornar-se inútil à produção.

Hannah Arendt nos fala ainda que os campos de concentração foram um laboratório, um experimento:

\begin{abstract}
Os campos são um Laboratório vivo que revelam que tudo é possível, que os humanos podem criar e habitar um mundo onde as distinções entre vida e morte, verdade e falsidade, aparência e realidade, corpo e alma, e até vítima e algoz são constantemente confundidas (...) os campos apresentam, primeiro, a morte jurídica; depois a destruição moral e finalmente que a individualidade do ser tem de ser esmagada (cf. HABIB, 1996, p. 65).
\end{abstract}

Todos estes termos, estes quadros explicativos, por mais densos que sejam, não abarcam a totalidade daquele experimento. A singularidade daquele ato violento, já apontada por diversos teóricos do tema, parece-me sem precedentes: mais do que torturá-los, escravizá-los, eliminá-los enquanto povo da face da terra, utilizá-los como cobaias, importava transformá-los em não homens. Para quê? Para quem? Eis o abismo que se apresenta ao historiador, quando ele se pergunta sobre o lapso entre intenção e resultado, causa e efeito.

Ora, meu objetivo não é o de apresentar uma tese alternativa às mencionadas, tampouco negar-lhes a validade; apenas demonstrar a dificuldade de acercarmo-nos do tema.

Para contribuir com este intuito, pretendo apresentar, ao lado das teses já enunciadas e segundo meu entendimento, os elementos de cristalização do ato violento, indagando-me sobre os sentimentos que levaram tantos indivíduos comuns a cooperarem com os campos de concentração, traçando ainda algumas analogias com outros fenômenos em que a violência se introduz na política. 


\section{Entre a violência simbólica e a violência física}

Em primeiro lugar, esclareço o que compreendo por violência: Todo $o$ ato de força contra a espontaneidade, a vontade e a liberdade de alguém (coagir, constranger, torturar, banalizar); todo ato de violação da natureza de alguém (violar); todo o ato de transgressão contra o que alguém define como justo e como direito (desnaturar, agredir, ofender); todo ato ou palavra que leva ao rebaixamento da dignidade humana (humilhar, ultrajar, desamparar).

Quanto à violência política, ou melhor, a violência no político, tomemos o exemplo daquela praticada nos regimes de caráter autoritário ou totalitário, essencialmente onde estes operam o terror, pois aí, a violência é radicalmente muda.

Nesses casos, sabemos que a violência é sempre exercida contra um outro, outro desenhado, real ou imaginariamente, como inimigo. Outro que, mesmo tendo perdido sua importância (ou até desaparecido), continua a fornecer as energias afetivas ao regime. Outro que, quando denunciado, encontrado e aprisionado, serve de reforço ao entusiasmo nutrido pelo chefe carismático ou pela restauração da ordem, como é o caso das ditaduras militares latino-americanas. Outro que, inclusive, está presente nas origens dos movimentos que prefiguram a instauração de regimes totalitários ou autoritários.

Para entendermos esse processo, resgatemos, como o fez o historiador Pierre Ansart, a dimensão socioafetiva de tais movimentos.

A eles precede sempre, segundo o autor, um conjunto de paixões políticas, alimentadas num pequeno grupo (geralmente, de caráter sectário), que são expressas de forma a denunciar, com intensa violência verbal (ou mesmo violência física), o inimigo: os imperialistas, os judeus, o Tratado de Versalhes, a burguesia, os criminosos, os subversivos. Quando identificados como forças do mal, o ódio é iniciado sem clemência, ao mesmo tempo em que é produzida uma identificação afetiva com o chefe do grupo (ANSART, 1983, p. 132).

Uma vez assumido o poder oficial, os prosélitos do movimento, que se tornam então os governantes, destroem as oposições formais, alojando seus "resíduos" em instituições tornadas oficiais - necessariamente 
denominadas como secretas, protegidas dos olhares dos demais e, em alguns casos, dos próprios donos do poder, que delegam a sua guarda ao segundo ou terceiro escalão do governo.

Segundo Ansart,

Estas instituições invisíveis se confundem com a lei, a lei do amor, já que os princípios que ela propõe são os fins mais elevados da sociedade (o sistema social e seu chefe); o amor faz a lei porque doravante não há mais distinção entre os amores propostos e os constrangimentos a partir dos quais se proíbem as transgressões (1983, p. 138 - tradução livre da autora).

É nesse espaço confinado, invisível, porém não plenamente desconhecido, que se encontra imageticamente o opositor. Nesse espaço confinado, do qual inclusive desviamos o olhar, sabemos que o mal, o erro, está aprisionado. Não sabemos ao certo o que fazer dele, sentimos apenas que, embora próximo, está impedido de agir.

Meu argumento pode ser reforçado quando levamos em conta o lugar do inimigo nos discursos oficiais, mesmo quando este já perdeu sua relevância numérica ou política. Embora exilado, deportado, preso ou mesmo morto, continua sendo apresentado como um mal ameaçador, um perigo iminente. Cito como exemplo o filme Der ewige Jude (O eterno judeu), de Fritz Hippler, produzido à época do nacional-socialismo, no qual cenas de um gueto judeu são projetadas alternadamente com cenas de ratos num celeiro, sendo simultâneas à seguinte locução:

Em todos os lugares onde surgem ratos, eles provocam a ruína do país, destruindo os bens e a alimentação dos homens. É assim que eles propagam doenças tais como a peste, a lepra, o tifo, a cólera etc. Eles são dissimulados, medrosos e cruéis e aparecem, na maioria das vezes, em bandos. Representam, entre os animais, o elemento de destruição pérfida e subterrânea. Exatamente como os judeus entre os homens. (apud LOSFELD, 1972, p. 202 - tradução livre da autora) 
Ele é um adversário que não pode ser tratado como mero opositor, porquanto dotado de um poder misterioso e absoluto; ${ }^{5}$ assim, os líderes do regime logram garantir continuamente a obediência de seus liderados, obediência que se pretende cega e sem limites. Obediência que resulta de uma lógica aterrorizadora.

Para melhor compreender tal dimensão, gostaria de me valer do esquema proposto por Roger Dadoun, quando procura explicar a violência praticada por grupos terroristas, e que me parece paradigmática para entendermos o caráter instrumental da violência no político.

Primeiro, porque, nesse caso, os terroristas, eles mesmos, elegem um espaço confinado (os aparelhos) para conviver, planejar e executar suas ações; segundo, porque tais grupos se percebem como fruto de uma violência anterior a eles; terceiro, porque, como nos regimes totalitários, praticam a violência em nome de - o chefe carismático, o partido, o grupo, a revolução - e, por último, por seus delírios paranóicos (há sempre uma ameaça contra um bem absoluto ${ }^{6}$ e, por via de consequência, contra eles mesmos, que são os seus legítimos representantes e protetores).

$\mathrm{O}$ ato violento é, portanto, sua última esperança. Ato que pressupõe, segundo o Roger Dadoun, três elementos:

Um drama que se encena a três, se considerarmos constitutitivo de um triângulo terrorista três elementos: o Grupo, o Sistema, a Massa. Entre eles, realizam-se estranhos e problemáticos cruzamentos que poderíamos esclarecer com a ajuda de uma analogia com a estrutura do psiquismo. Centrado, concentrado sobre si mesmo, egocêntrico, narcisista, pretendendo autonomia e identidade, o Grupo corresponderia convenientemente ao Eu, instância da consciência, da iniciativa, do domínio, do discurso; valor dinâmico, coerente e da posteridade. O Grupo se dirige contra o Sistema, que poderia representar o Superego, pois ele profere as proibições, dita a lei e a norma, detém a autoridade e impõe a repressão. O Grupo e o Sistema, dualidade belicosa e armada, visam juntos um terceiro termo, que é a Massa - ou "povo", ou "proletariado", ou "nação", "comunidade", etc. -

5 Sobre o poder que se atribui ao inimigo, ver: GIRARDET, R. Mitos e mitologias políticas. São Paulo: Cia. das Letras, 1987. p. 62 et seq.

6 Para entendermos com maior profundidade este conceito, ver: ARENDT, H. A vida do espírito. Rio de Janeiro: Relunce-Dumará, 1993a. 
força bruta, inconsciente, reservatório de energia, que compararíamos validamente ao Isso. O Grupo afirma trabalhar - ele que é Eu, consciência, vontade, cabeça - pela totalidade do Corpo Social,... (DADOUN, 1998, p. 38)

Inspirando-nos nesta analogia, detenhamo-nos em outros processos políticos nos quais a violência assume papel central.

No processo da tortura, pode ser representado este mesmo triângulo: o $E u$, que é o governo (a elite do sistema responsável pelos aparelhos oficiais de repressão ou o próprio torturador, que representa ou se imagina governo); o Superego, que são os subversivos, cujo poder é imaginado como de maior envergadura do que o próprio poder do governo - na tortura não importa apenas fazer falar, mas sobretudo fazer calar o inimigo, este, freqüente e ironicamente, apresentado como terrorista. E um Isso, que não é a massa ou a população, mas a ordem. Quando realizei pesquisa no arquivo do Dops, relativa aos mecanismos de repressão sob o regime autoritário no Brasil, entre 1964 a 1985, pude observar que tanto o subversivo visto como terrorista em potencial quanto a obsessão pela ordem - a ser mantida com uma lógica tipicamente militar - eram as principais justificativas alegadas pelos informantes do sistema. ${ }^{7}$

Um outro exemplo que não deixa de manter vínculos com o passado nazista: a prática da delação, que também é secreta e, aos olhos de seus autores, invisível. Para ilustrar esta representação, valho-me do exemplo da ex-Alemanha Oriental, país em que, no lapso de quarenta anos, a prática da delação e da suspeição afligiram praticamente todos os seus cidadãos.

A Alemanha Oriental, segundo Hockenos, "fundamentou sua legitimidade como estado não em suas credenciais nacionais, como um estado alemão, mas sim em sua identidade política, como um estado socialista" (1995, p. 92); sob a tutela da União Soviética, tinha a enfrentar dois inimi-

7 Sobre este aspecto, ver: MAGALHÃES, M. B. de. A lógica da suspeição: sobre os aparelhos do Estado à época do regime militar. Revista Brasileira de História, São Paulo, v. 17, n. 34, p. 203-220, 1997. Não quero, com esta afirmativa, fazer crer que interpreto a ditadura militar brasileira como uma manifestação totalitária. Entendo, como Juan Linz (1980), que os regimes militares latino-americanos foram regimes autoritários com pluralismo limitado. No entanto, considero que os aparelhos repressivos desses mesmos regimes possuíam a mesma estrutura socioafetiva dos sistemas totalitários, principalmente quanto às justificativas para o emprego da violência. 
gos: o seu próprio passado, identificado como fascista, e a sua cultura (encarnada também no estado vizinho - a República Federal) - denominada em tom pejorativo de germanidade. Um dos símbolos mais marcantes dessa ruptura, pelo menos para mim, que tive a oportunidade de observá-lo de perto, foi o desenho urbano da capital da Saxônia, Erfurt. Aquela cidade tinha sido celebrada no passado como a terra que vira Lutero amadurecer suas convicções em favor da Reforma da Cristandade; ali estava a universidade que freqüentara e o mosteiro onde vivera por dez anos, patrimônio religioso e histórico de fundamental importância. Ali a violência contra a memória de seus habitantes se me tornou particularmente nítida.

O centro da cidade foi praticamente abandonado, deixado envelhecer, permanecendo deserto; nas casas antigas, moravam poucas famílias, as mais desafortunadas, provavelmente. Já em sua periferia, foi construído um anel de blocos de edifícios de quatro andares, com apartamentos de padrão uniforme, e, entre eles, pequenos centros de comércio e de diversão, constituindo o espaço de sociabilidade de seus habitantes. Ali, uma outra Erfurt, totalmente estrangeira à "velha" e germânica Erfurt. Aquele centro se me soou como uma ruína, não por evocar um passado glorioso, mas pela caducidade que se pretendia imprimir àquela História.

Nessa pátria socialista, as imagens de Franz Kafka se concretizaram: em seus arquivos secretos, a Staatssichereitdienst - STASI - arrolou 6 milhões de dossiês pessoais, sendo 4 milhões de habitantes desse território e 2 milhões da República Federal. De cada 3 cidadãos adultos da República Democrática Alemã, pelo menos um era suspeito ou indiciado como suspeito de subversão. Para que tais arquivos atingissem esse número, seus governantes contaram com nada menos do que 100 mil pessoas, entre funcionários e colaboradores (Mitarbeiter). Segundo Joachim Gauck, tais indivíduos consentiam em entrar em igrejas, disfarçando-se de crentes, em escolas, universidades e diversas outras instituições com o objetivo de colher informações para o Estado, com o velado propósito de verem resolvido seus próprios problemas com a polícia. "Bem, se você cooperar conosco, seus problemas se resolvem mais facilmente" (1991, p. 28), era o convite dos funcionários para que os Mitarbeiter se cooperassem. Problemas como regularizar a infinidade de papéis exigida pela burocracia governamental, suspeita de espionagem, de manter relações com cidadãos da República Federal (o que era bem plausível, uma vez que muitos possuíam parentes naquele outro país), suspeita de comprometimento com o passado nazista, 
necessidade de um bom currículo para a admissão ao serviço público, eram obstáculos, entre outros, que podiam ser superados por meio da delação.

Nesse sistema, o $E u$ delator é um grupo ou um indivíduo aterrorizado por deter um segredo que Ele, o governo, exige saber, o qual é revelado em nome de um Isso, a sua libertação, ainda que jamais definitiva ou estável.

Finalmente, no nazismo, triângulo semelhante pode ser observado: o $E u$, neste caso, é o partido, ou mesmo o próprio Führer, que todos na verdade desejam encarnar; o Superego, os inimigos do Estado (judeus, comunistas, homossexuais, testemunhas de Jeová, ciganos); o Isso, a raça ariana, que necessita de uma limpeza, mas também, o próprio chefe, Adolf Hitler, em nome de quem é necessário abdicar inclusive de sua própria vida privada.

Creio ser de fundamental importância tecer considerações sobre o nazismo e seus laboratórios do tudo é possível (para empregar um termo de Hannah Arendt), porque foram neles, como já mencionei, que a violência assumiu o caráter, por excelência, de experimento.

Laboratórios de morte, mas de uma morte muito peculiar: a morte segmentada; morte jurídica, ao que se sucedia a morte moral e só então a morte física. Violência desprovida de critérios utilitários. Violência que transformou o assassinato em um experimento técnico, como por exemplo, a utilização do Zyclon B, para que as vítimas morressem mais rapidamente "técnica" justificada porquanto desta maneira, não era dado tempo para que, devido ao medo, as vítimas defecassem e "sujassem" a câmara de gás. $\mathrm{Ou}$, no outro extremo, pequenos atos violentos, e eu me lembro de um depoimento em que, uma mulher, sofrendo de renite alérgica, carregava consigo um lenço, o qual lhe foi retirado apenas para vexá-la diante dos outros, devido a seu corrimento nasal.

Para vislumbrar como a predisposição à violência foi neste caso potencializada, citemos alguns excertos das memórias do comandante de Auschwitz, Rudolf Hoess; ele, jamais apresentando-se como sádico ou cruel, fala de sua própria experiência, a qual constitui, em nossa concepção, um microcosmos da estrutura socioafetiva que produziu os perpetradores dos crimes e brutalidades durante o regime nazista.

De seu entusiasmo face à nova Alemanha: 
Nestes anos, a Alemanha estava vivendo um grande progresso, a indústria e o comércio estavam florescentes como nunca. $\mathrm{O}$ sucesso obtido por Adolf Hitler com a política externa saltava aos olhos e impunha o silêncio àqueles que ainda se arriscavam a combater o regime. O partido dominava o Estado. Seu sucesso era inegável, seus métodos e seu princípio eram os únicos justos: esta era a minha profunda convicção. (HOESS, 1995, p. 94 tradução livre da autora)

Do processo de sua despersonalização em favor à causa do líder:

Lutei muito tempo antes de fazer uma escolha entre minha convicção pessoal e minha fidelidade aos juramentos que prestei às S.S. e ao Führer. Quantas vezes não me perguntei se tinha o direito de desertar? (...) Nacional-socialista desde longa data, eu estava firmemente convencido da necessidade dos campos de concentração. Era necessário colocar os inimigos do Estado sob guarda (...) era o único meio de proteger o povo contra as suas atividades nefastas. Estava firmemente convencido que esta tarefa só podia ser cumprida pelas S.S., encarregadas da defesa do novo Reich (p. 91-92). (Grifos meus)

De sua identificação fusional com o chefe, o comandante do campo de concentração de Sachsenhausen, onde Hoess exerceu uma função administrativa, antes de servir como comandante em Auschwitz:

O comandante,,.. ainda que duro e severo, era todavia animado por um sentimento fanático do dever e de um desejo sincero de ser justo. Este veterano do nacional socialismo (...) me serviu de modelo, parecia-me que minha própria natureza era um reflexo da sua. Ele também passava por fases de benevolência e de sensibilidade. Mas em todas as suas atividades, dava provas de severidade e de dureza implacáveis. Eu me inspirava em seu exemplo para fazer calar todo o meu impulso de fraqueza e para me submeter às duras exigências de meu dever de S.S. (...) Ainda hoje não compreendo como tive tanto sangue frio para dar ordens de atirar. (....) penso que o que se exigia de mim ultrapassava as forças humanas (...) no entanto Eicke [o comandante citado] continuava suas exortações para nos incitar 
a uma dureza ainda maior. Um S.S. deve ser capaz, dizia-nos ele, de aniquilar seus próprios parentes se eles se rebelarem contra o Estado ou contra as concepções de Adolf Hitler. (...) O dever de destruir o inimigo interno do Estado não se distingüe em nada daquele que lhes obriga a matar seu adversário no campo de batalha (p. 94-95 e 101).

De sua autêntica incapacidade de pensar, termo que empresto de Hannah Arendt, ao se referir a Eichmann (1999), e que, ao meu ver, é plenamente aplicável à sinceridade de Hoess, quando da redação dos capítulos finais de sua biografia, já preso pelos aliados e no aguardo de sua sentença:

No momento em que se procedeu a subdivisão de Auschwitz, sob a sugestão de Pohl, este me deixou a escolha entre dois postos: comandante de Sachsenhausen ou chefe do Büro D1.

Para Pohl, era uma excepcionalidade permitir que o interessado escolhesse seu posto. (...) ele me deu vinte e quatro horas para refletir. Queria se mostrar benevolente porque a seu juízo eu deveria estar ressentido por deixar Auschwitz.

E de fato, num primeiro momento, senti uma certa tristeza de me separar de Auschwitz; sentia-me muito ligado a este campo no qual eu tinha tido de vencer tantas dificuldades e tantos abusos, onde tantos e pesados problemas ainda estavam por ser resolvidos (p. 216 - grifos meus).

De seu ressentimento para com aqueles a quem considera ter servido:

Que o grande público continue pois a me considerar uma besta feroz, um sádico cruel, como o assassino de milhões de seres humanos: as massas não saberão fazer uma outra idéia do antigo comandante de Auschwitz. Elas não compreenderão jamais que eu, eu também tenho um coração... (p. 257) 


\section{O experimento: entre a memória e a história}

Feitas estas considerações sobre sobre o que, no plano das paixões políticas, cooperou para que Auschwitz fosse possível (o líder carismático, o espaço confinado, a garantia de anonimato e impunidade, a colaboração de inúmeros indivíduos, a tecnologia empregada, entre outros), indago, para concluir minhas reflexões, sobre o significado dessa experiência para a História: para tanto, sem pretender uma resposta definitiva, valho-me do testemunho de um sobrevivente, Primo Levi, que afirmou ter sido o objetivo último dos perpetradores a desumanização dos adversários. E que, 36 anos após ter feito tal constatação, perguntou-se: Até que ponto os nazistas lograram seu intuito? Sua resposta foi afirmativa: ${ }^{8}$

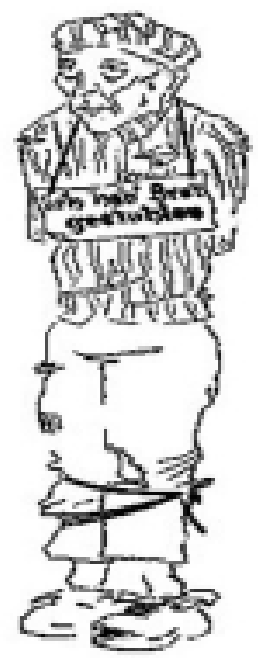

Desenhado no Campo de Concentração de Oranienburg, tendo a placa a seguinte inscrição: "Roubei Pão"
...Vivêramos durante meses ou mesmo anos num nível animalesco: nossos dias tinham sido assolados, desde a madrugada até a noite, pela fome, pelo cansaço, pelo frio, pelo medo, e o espaço para pensar, para raciocinar, para ter afeto, tinha sido anulado. Suportáramos a sujeira, a promiscuidade e a destituição, sofrendo com elas muito menos do que sofreríamos na vida normal, porque nosso metro moral havia mudado. Além disso, todos roubáramos: na cozinha, na fábrica, no campo, roubáramos "dos outros", da contraparte, mas era furto do mesmo modo; alguns (poucos) se rebaixaram até o ponto de roubar o pão do próprio companheiro. Esquecêramos não só nosso país e nossa cultura, mas a família, o passado, o futuro que nos havíamos proposto, porque, como animais, estávamos restritos ao momento presente (1990, p. 42).

8 Refiro-me aqui às suas considerações na obra É isto um homem? redigida entre 1946 e 1947, e Afogados e Sobreviventes, redigida entre 1979 e 1985. 
De sua memória sobre aqueles anos de guerra, fala-nos ainda de uma zona cinzenta, espaço de poder (também invisível) que se interpunha entre as vítimas e os perpetradores. Nesta, encontravam-se os colaboradores (voluntários ou involuntários, se é que se podemos empregar esta palavra).

Figura terminal da zona cinzenta, conforme Levi, era o Sonderkommando (comando especial), ou seja, o grupo de prisioneiros que se incumbia das tarefas mais degradantes, como colocar nas câmaras de gás os indivíduos "selecionados", retirar os cadáveres de lá, extrair seus dentes de ouro, arrancar-lhes os cabelos - que serviam para o fabrico de colchões -, limpar os fornos, organizar as próximas filas.

Havia aqueles que não participavam diretamente dos crimes: mas, por saberem o idioma alemão ou o polonês, por serem fisicamente mais aptos, por poderem trabalhar na enfermaria, tinham suas vidas poupadas.

Fora da zona cinzenta, encontravam-se os "muçulmanos" (Muselman), ${ }^{9}$ jargão com que se designavam os "normais"; aqueles que ou não exerciam uma atividade útil ao campo ou que não queriam ou não tinham a coragem de furtar e que obedeciam passivamente às ordens sem quaisquer protestos. Estes enfraqueciam mais rapidamente, ficando com uma aparência cadavérica, magérrimos e doentes; o Muselman era também conhecido como cadáver ambulante, pois se encontrava efetivamente em estado de grave apatia, como se não sentisse mais nada. Parecia ter perdido toda a consciência e toda a vontade.

Prisioneiros com essas características sucumbiam mais depressa, pois sucumbir era mais fácil do que sobreviver. Sim, porque segundo Levi, ao se executar as ordens recebidas, obedecer a disciplina e realizar seu trabalho, alimentar-se apenas de sua ração, a vida não duraria mais do que 5 ou 6 meses. E ninguém, nem mesmo os outros prisioneiros, nutriam por eles qualquer sentimento de solidariedade. Eram repugnantes, queixosos, chorosos.

À figura do Muselman, contrapunha-se a dos que tinham maiores chances de sobreviver, como o prisioneiro Elias, um quase anão narrado por Levi, que roubava, trabalhava, ria, praguejava e cantava:

9 O termo muçulmano, de origem árabe, significa aquele que se submete voluntariamente à vontade divina. Sobre este personagem, ver LEVI, P. É isto um homem? Rio de Janeiro: Rocco, 1988. p. 88 et seq. 
Elias sobreviveu à destruição externa, porque é fisicamente indestrutível; resistiu à aniquilação interna porque é demente. Ele é, portanto, um sobrevivente: o mais apto, o espécime humano mais adequado a esta maneira de viver. $(1988$, p. 99)

Homens como Elias, segundo as memórias de Levi, eram denominados com o termo Prominenz. Proeminentes eram os funcionários dos estratos superiores e inferiores, os guardas, os garis, os cozinheiros, os encarregados das latrinas e das duchas e, ainda, os colaboradores da repressão, personagens assim descritas por Levi:

São o típico produto da estrutura do Campo de Concentração alemão: basta oferecer a alguns indivíduos em estado de escravidão uma situação privilegiada, certo conforto e uma boa probabilidade de sobrevivência, exigindo em troca a traição da natural solidariedade com os companheiros, e haverá por certo quem aceite. (...) será, então mais odioso e odiado quanto maior for o poder a ele concedido. Quando lhe for confiado o comando de um grupo de infelizes com direito de vida e morte sobre eles, será cruel e tirânico, (...) Acontecerá ainda que, a sua capacidade para odiar, frustrada frente aos opressores, se volte, incessantemente, contra os oprimidos (1988, p. 92).

Cada um por si, mentindo, subordinando, agredindo ou mantendo alguns de seus padrões morais e, por isso, sucumbindo.

De um lado, as vítimas; de outro, os algozes com suas intenções e ideologia. E entre eles, a zona cinzenta, na qual se encontravam os homens dos estratos inferiores do regime e as vítimas que sobreviveriam, não por heroísmo, solidariedade, ou mesmo vontade: talvez, por desejo de vingança; por certo, pela fé que alguns nutriam em Deus; ou ainda, pelo pouco tempo em que lá se encontravam. Ao que se somou, com certeza, a necessidade de contar o que lhes sucederia.

Esses homens foram e são nossos principais documentos, nossas fontes. Mas não apenas eles; também os algozes, que juntos, constelam precisamente o que penso ter sido a experiência mais singular de Auschwitz: a zona cinzenta de que nos fala Levi, onde tanto vítima como perpetrador ainda que por motivos muito diferentes - acabam por perder a empatia pelo gênero humano. 


\section{Referências}

AGAMBEM, G. Ce qui reste d'Auschwitz. Paris: Payot \& Rivages, 1999.

ANSART, P. La gestion des passions politiques. Lausanne: L'Age d'Homme, 1983.

ARENDT, H. Religião e política. In: ARENDT, H. A dignidade da política. Rio de Janeiro: Relume-Dumará, 1993.

ARENDT, H. A vida do espírito. Rio de Janeiro: Relume-Dumará, 1993a.

ARENDT, H. Eichmann em Jerusalém: um relato sobre a banalidade do mal. São Paulo: Cia. das Letras, 1999.

BENHABIB, S. The reluctant modernism of Hannah Arendt. London: Sage Publications, 1996.

BETTELHEIM, B. Survivre. Paris: Laffont, 1979.

BRASIL: nunca mais. Rio de Janeiro: Vozes, 1985.

COUTARDE, P.; CADARS, P. Histoire du cinéma nazi. Paris: E. Losfeld, 1972.

DADOUN, R. A violência. Rio de Janeiro: DIFEL, 1998.

FELDMANN, S. 1945: hora zero de um novo tempo. Cinqüentenário da Segunda Guerra mundial. Curitiba: Instituto Goethe/Programa de Pós-Graduação em História da Universidade Federal do Paraná, 1995.

FOUCAULT, M. Em defesa da sociedade. São Paulo: Martins Fontes, 1999.

GAUCK, J. Das unheimliche Erbe der DDR: die STASI-Akten. Berlim: Ro-Ro-Ro Aktuell, 1991.

GIRARDET, R. Mitos e mitologias políticas. São Paulo: Cia. das Letras, 1987.

HOCKENOS, P. Livres para odiar; neonazistas: ameaça e poder. São Paulo: Scritta, 1995.

HOESS, R. Rudolf Hoess: le commandant d'Auschwitz parle. Paris: La Découverte, 1995.

LEVI, P. Os afogados e os sobreviventes. Rio de Janeiro: Paz e Terra, 1990.

LEVI, P. É isto um homem? Rio de Janeiro: Rocco, 1988.

LEVI, P. Conversations et entretiens. Paris: R. Laffont, 1998.

LINZ, J. et al. Regimes autoritários. In: O’DONNEL, G. (Org.). O Estado autoritário e movimentos populares. Rio de Janeiro: Paz e Terra, 1980. 
MAGALHÃES, M. B. de. A lógica da suspeição: sobre os aparelhos repressivos do Estado à época do regime militar. Revista Brasileira de História, São Paulo, v. 17, n. 34, p. 203-220, 1997.

MILGRAM. Obedience to authority: an experimental view. New York: Harper Colophen, 1969.

PETERS, E. História da tortura. Lisboa: Teorema, 1985.

RÜSEN, J. Explicar o holocausto - de que jeito? O livro de Daniel Goldhagen criticado à luz da teoria da História. História: Questões e Debates, Curitiba, v. 14, n. 26/27, p. 116-131, jan./dez. 1997.

SEIXAS, J. Comemorar entre memória e esquecimento: reflexões sobre a memória histórica. História: Questões e Debates, Curitiba, n. 32, p. 75-95, jan./jun. 2000. 